\title{
HUBUNGAN RIWAYAT KONTAK DENGAN PENDERITA TB PARU DEWASA DAN RIWAYAT IMUNISASI BCG DENGAN KEJADIAN TB PARU PADA ANAK DI POLI ANAK RS HUSADA
}

\author{
Ernawati*) \\ Wiwik Lestari**) \\ *)Dosen Akademi Keperawatan RS Husada, Jakarta, 10730, Indonesia \\ **)RS Husada, Jakarta, 10730, Indonesia; Program Studi Ilmu Keperawatan \\ Stikes Binawan
}

\begin{abstract}
ABSTRAK
Angka kematian anak yang disebabkan TB di Indonesia sebesar 91.368 pertahun atau setiap hari 250 orang meninggal (Depkes RI, 2010). Penelitian ini dilakukan untuk memperoleh gambaran hubungan riwayat kontak dengan penderita TB dewasa dan riwayat imunisasi BCG dengan kejadian TB Paru pada Anak di Ruang Poli Anak RS Husada. Penelitian ini menggunakan metode deskriptif korelatif. Populasi dalam penelitian ini adalah semua pasien anak yang berusia 6 bulan - 12 tahun yang berobat ke Klinik Anak RS Husada Jakarta Pusat pada bulan Maret 2015 - April 2015. Sampel pada penelitian ini sebanyak 41 orang dengan tehnik pengambilan sampel accidental sampling. Hasil penelitian menunjukkan Ada hubungan yang bermakna antara kontak dengan penderita dewasa dengan kejadian TB Paru pada anak di Poli Anak RS Husada dan tidak ada hubungan yang bermakna antara imunisasi BCG dengan kejadian TB Paru pada anak di Poli Anak RS Husada.
\end{abstract}

Kata kunci : tuberkulosis paru, anak, kontak penderita, riwayat imunisasi BCG

\begin{abstract}
The infant mortality rate caused by TB in Indonesia is 91,368 per year or 250 people everyday (Depkes RI, 2010). This study was conducted to obtain a description of the relationship history of contact with adult tuberculosis patients and history of $B C G$ immunization with the incidence of Pulmonary TB in Children in Child Poly Room Husada Hospital. This research uses correlative descriptive method. The population in this study were all pediatric patients aged 6 months - 12 years old who went to the Husada Hospital Clinic of Central Jakarta Hospital in March 2015 - April 2015. The sample in this study were 41 people with accidental sampling sampling technique. The results showed that there was a significant correlation between contact with adult patients with the incidence of Pulmonary TB in children in Poli Anak Husada Hospital and no significant relationship between BCG immunization with the incidence of Pulmonary TB in children in Poli Anak Husada Hospital.
\end{abstract}

Keywords: pulmonary tuberculosis, child, patient contact, history of BCG immunization 
PENDAHULUAN

Rencana Pembangunan Nasional Jangka Panjang (RPJP) 2005-2025 disebutkan bahwa pembanguan sumber daya manusia untuk terwujudnya manusia Indonesia yang sehat, cerdas, produktif dan masyarakat yang semakin sejahtera (Bappenas, 2005). Gambaran masyarakat Indonesia di masa depan yang ingin dicapai adalah masyarakat yang antara lain hidup dalam lingkungan yang sehat dan mempraktekkan perilaku hidup bersih dan sehat. Lingkungan yang sehat termasuk didalamnya bebas dari penyakit menular.

Salah satu penyakit menular yaitu tuberkulosis paru. Tuberkulosis (TB) merupakan masalah yang serius bagi dunia, karena menjadi penyebab kematian terbanyak dibanding dengan penyakit infeksi lain.Diperkirakan sekitar sepertiga penduduk dunia telah terinfeksi oleh Mycobacterium Tuberkulosis. Pada tahun 1995, diperkirakan ada 9.000.000 pasien TB Paru dan 3.000.000 kematian akibat TB Paru di seluruh dunia. Diperkirakan 95\% kasus TB Paru dan 98\% kematian akibat TB Paru di dunia, terjadi pada Negara-negara berkembang (Depkes RI. 2007).
Menurut Depkes RI (2007) anak merupakan penerus cita-cita bangsa. Oleh karena itu, anak harus mendapat perhatian yang sempurna dalam memenuhi perkembangan dan pertumbuhan baik fisik maupun mental sejak dini. Pertumbuhan dan perkembangan anak dipengaruhi berbagai faktor yang satu sama lain saling berhubungan seperti faktor kebudayaan, nutrisi dan kesehatan anak itu sendiri.Pada masa anak-anak ini mereka cenderung lebih rentan untuk tertular suatu penyakit karena daya tahan tubuh mereka belum bekerja secara optimal dan sempurna, serta keadaan fisik mereka tidak sekuat orang dewasa.

Pada usia anak-anak penyakit TBC mudah menyebar ke bagian tubuh lain. Mula-mula kuman bersarang di paru-paru melalui aliran darah kuman dapat menyebar kebagian tubuh lainnya, terutama otak, jantung, ginjal dan tulang. Keterlambatan membuat diagnose dapat menyebabkan komplikasi yang serius seperti meningitis dan perikarditis. Sehingga dapat menyebabkan kematian dan jika hiduppun akan menimbulkan kecacatan (Jurnal Respiratori, 2009). 
Beberapa faktor yang berhubungan dengan terjadinya TB Paru pada anak antara lain : system imunitas yang belum sempurna, kontak erat dengan orang dewasa penderita TB disekitarnya (orang tua, kerabat dekat, pengasuh) kurangnya kesadaran orang tua untuk segera melakukan vaksinasi BCG pada bayi baru lahir (Wahyu, 2008).Sistem imunitas yang belum sempurna ditambah adanya kontak erat dengan penderita TB Paru kebanyakan karena penularan dari penderita dewasa.

Penularan penyakit tuberkulosis dari udara yang tercemar oleh mycobacterium tuberkulosayang dilepaskan atau dikeluarkan oleh penderita saat batuk dalam bentuk droplet (percikan dahak), balita dapat terinfeksi kalau droplet tersebut terhidup kedalam saluran pernafasan lalu menyebar dari paru-paru kebagian tubuh vital lainnya (Depkes RI,2005).

Salah satu usaha mencegah terjadinya penyakit TB Paru perlu dilakukan imunisasi, Imunisasi adalah tindakan untuk memberikan perlindungan (kekebalan) di dalam tubuh bayi dan anak. Tubuh mempunyai cara dan alat untuk mengatasi penyakit sampai batas tertentu. Itulah sebabnya, pada beberapa

jenis penyakit yang dianggap berbahaya, dilakukan tindakan imunisasi atau vaksinasi.

Program imunisasi di Indonesia dimulai pada tahun 1956 dan pada tahun 1990, Indonesia telah mencapai status Universal Child Immunization (UCI), yang merupakan suatu tahap dimana cakupan imunisasi di suatu tingkat administrasi telah mencapai $80 \%$ atau lebih. Saat ini Indonesia masih memiliki tantangan mewujudkan $100 \%$ UCI Desa/Kelurahan pada tahun 2014 (Pusat Komunikasi Publik, 2011) .

Faktanya tidak semua penyakit dapat dicegah dengan vaksinasi, termasuk vaksinasi BCG untuk mencegah infeksi tuberkulosis. Menurunnya perlindungan BCG serta meningkatnya kerentanan akan daya tahan tubuh yang rendah. Hal ini disebabkan oleh keadaan gizi yang buruk, lingkungan yang tidak bersih, keadaan sosial ekonomi yang rendah dan pola hidup yang tidak sehat. Berkurangnya perlindungan oleh BCG dimungkinkan terjadi karena banyak faktor misalnya prosedur pemberian BCG yang tidak efektif dan efisien (Islamiati, 2009). 
Penyakit TB pada anak dapat dicegah dengan imunisasi baik secara aktif maupun pasif. Imunisasi pasif berarti kekebalan yang secara alami / bawaan berupa antibodi diperoleh dari ibunya selama perkembangan janin intrauterine yang dapat melewati plasenta dan dari kolostrum air susu ibu. Antibodi yang diperoleh dapat memberikan perlindungan segera dan meningkatkan resistensi bayi terhadap agen infeksius yang sangat virulen dan toksin yang berpotensial mematikan seperti baksil TB. Sehingga mungkin saja anak yang tidak mendapatkan imunisasi aktif seperti BCG tetapi tidak terkena TB paru. Namun lama perlindungan imunitas pasif hanya sekitar 6-9 bulan artinya perlindungan imunitas pada bayi sama dengan yang memiliki ibunya sampai anak dapat secara aktif membentuk sendiri respon imunitasnya (Sherwood, 2009).

Anak yang sudah mendapat imunisasi BCG masih mungkin menderita penyakit TB (Tuberkulosis) primer yang ringan tetapi dapat terhindar dari penyakit TB yang berat. Penyebaran basil TB dapat terjadi melalui pembuluh darah ke seluruh jaringan paru maupun jaringan lain. Komplikasi lebih lanjut dapat terjadi TB selaput paru, meningitis, TB kulit, infeksi sendi dan TB tulang yang dapat mengakibatkan cacat seumur hidup (Suryaatmadja, 2009). Penyakit TB pada bayi dan anak yang disebut juga TB primer biasanya dimulai perlahan-lahan sehingga sukar ditentukan saat timbulnya gejala pertama. Bila tidak diobati sedini mungkin dan setepat-tepatnya maka dapat timbul komplikasi yang berat dan reinfeksi pada usia dewasa (Ngastiyah, 2009).

Sampai saat ini penyakit TB merupakan penyakit infeksi yang masih menjadi masalah kesehatan dunia. Dalam situasi dunia yang memburuk dengan meningkatnya jumlah kasus TB. Pada tahun 2011 Indonesia (dengan 0,38-0,54 juta kasus) menempati urutan keempat setelah India, Cina, Afrika Selatan. Indonesia merupakan negara dengan beban tinggi TB pertama di Asia Tenggara yang berhasil mencapai target Millenium Development Goals (MDGs) untuk penemuan kasus TB di atas $70 \%$ dan angka kesembuhan $85 \%$ pada tahun 2006.

Estimasi jumlah pasien TB anak adalah sekitar 10-15\% dari jumlah kasus dewasa. Laporan TB anak di Indonesia pada tahun 2012 menyatakan jumlah kasus TB anak $8,2 \%$ dari seluruh kasus, namun 
permasalahannya adalah jika dirinci data dari masing-masing provinsi, angkanya bervariasi antara 1,7-15,6\%.

Menurut Survey Kesehatan Rumah Tangga (SKRT) tahun 2012 bahwa angka kematian anak yang disebabkan TB di Indonesia sebesar 91.368 pertahun atau setiap hari 250 orang meninggal (Depkes RI, 2010).

Berdasarkan data kunjungan di Klinik Anak RS Husada Jakarta, angka kunjungan pasien yang menderita penyakit BP/ TB pada anak dimana status imunisasi BCG pada anak ada yang sudah diberikan ada pula yang belum/tidak di imunisasi. Jumlah anak yang menderita TB paru pada tahun 2012 terdapat 90 kasus ( $2,11 \%$ ),dan jumlah anak yang menderita TB Paru pada tahun 2013 dan 2014 sebanyak 114 kasus ( 2,67 \% ).

Secara global, terdapat 8.800.000 kasus baru TB di dunia pada tahun 2010 dengan People Living With TB 12.000.000 kasus, New TB cases per 100.000 Population 128 kasus, TB Deaths 1.100.000 kasus, TB Deaths per 100.000 population 15 kasus (Hendry J, WHO, Global Tuberculosis Control, 2011). Adapun lima peringkat Negara dengan proporsi kasus TB terbanyak pada tahun 2011.

\section{METODE}

Penelitian ini menggunakan penelitian deskripsi korelasi yaitu jenis penelitian yang bertujuan untuk menemukan ada tidaknya hubungan antara dua variabel (Nursalam, 2008). Rancangan penelitian yang digunakan adalah Cross Sectional yaitu penelitian yang dilakukan pada satu kali dan satu waktu,tidak ada follow up serta untuk mencari hubungan antara variabel independen (faktor resiko) dengan variabel dependen (efek),dengan cara membagikan kuesioner pada ibu yang membawa anaknya ke Klinik Anak RS Husada Jakarta Pusat. Populasi dalam penelitian ini adalah semua pasien anak yang berusia 6 bulan - 12 tahun yang berobat ke Klinik Anak RS Husada Jakarta Pusat pada bulan Maret 2015 April 2015. Sampel pada penelitian ini sebanyak 41 orang.

Adapun tehnik pengambilan sampel pada penelitian ini adalah Accidental sampling. Accidental sampling merupakan teknik sampling dimana orang yang dijadikan sampel adalah orang yang kebetulan bertemu dengan peneliti berdasarkan karakteristik yang dimiliki sebagai sampel pada saat penelitian (Sudjana, 1996). Kriteria Inklusi pada penelitian ini 
adalah responden yang membawa anaknya dengan usia 6 bulan - 12 tahun ke Klinik Anak RS Husada, baik yang menderita TB maupun yang tidak menderita TB, membawa atau menunjukkan Kartu / Buku Imunisasi anaknya dan responden dapat menjawab seluruh pertanyaan secara lengkap. Penelitian ini rencana akan dilakukan di Poliklinik Anak Rumah Sakit Husada Jakarta Pusat pada bulan Maret 2015 April 2015.

\section{HASIL}

Hasil analisa univariat ini dilakukan untuk mendapat gambaran tentang distribusi frekuensi kontak dengan penderita TB dewasa, distribusi frekuensi imunisasi BCG balita terhadap kejadian TB paru anak di Rumah Sakit Husada Jakarta tahun 2015. Hasil penelitian ini menunjukkan bahwa sebagian besar responden sebanyak 25 orang (61\%) mengalami kontak langsung dengan penderita TB dewasa, sebagian kecil responden $12(29,3, \%)$ yang tidak di Imunisasi $\mathrm{BCG}$, responden dengan $\mathrm{TB}$ Paru sebanyak $28(68,3 \%)$ dan yang tidak menderita penyakit TB Paru sebanyak 13 ( $31,7 \%$ ), responden dengan usia 0-5 tahun sebanyak $32(78 \%)$ dan yang usia 6-12 tahun sebanyak 9 (22\%), sebagian besar responden dengan usia 2 bulan sebanyak $21(51,2 \%)$ usia yang diberikan imunisasi, sebagian besar responden diberikan imunisasi BCG di Rumah Sakit sebanyak 15 (36,6\%), sebagian besar responden berpendidikan SMA sebanyak 21 $(51,2 \%)$, responden yang bekerja sebanyak $26(63,4 \%)$ dan yang tidak bekerja sebanyak $15(36,6 \%)$.

Analisa bivariat dilakukan untuk mengetahui hubungan variabel independen (riwayat kontak dengan penderita dewasa dan riwayat imunisasi BCG ) dan variabel dependen ( kejadian TB Paru ) di Poli Anak RS Husada pada bulan Maret - April 2015 dapat dilihat pada tabel - tabel berikut :

Tabel 1

Hubungan Riwayat Kontak dengan Penderita TB Dewasa dengan Kejadian TB Paru pada Anak di Poli Anak RS Husada pada bulan Maret

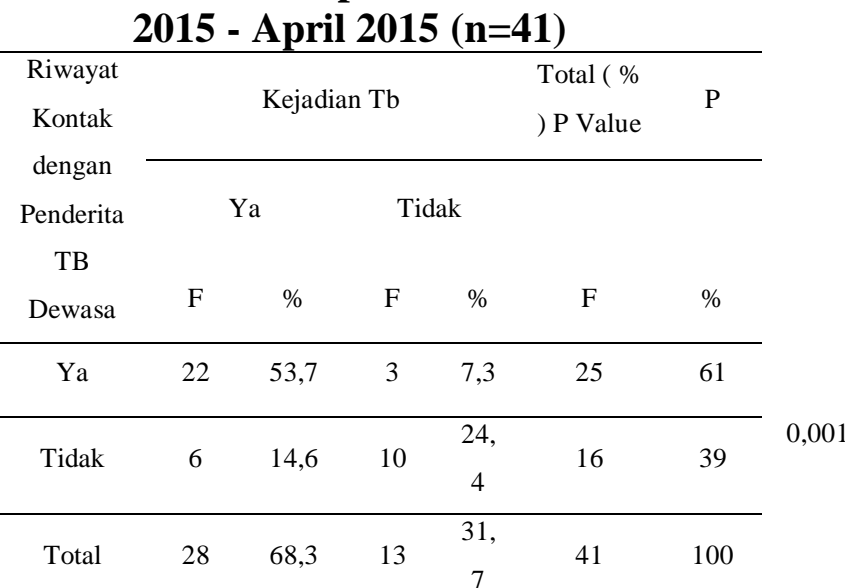


Dari 25 anak yang mengalami riwayat kontak dengan penderita TB dewasa terdapat $22(53,7 \%)$ menderita TB Paru, dan dari 16 anak tidak kontak dengan penderita dewasa terdapat $6(14,6 \%)$ mengalami TB Paru. Secara statistik dengan melihat derajat signifikasi didapat hubungan yang bermakna antara riwayat kontak dengan penderita TB dewasa dengan kejadian TB Paru pada anak dengan $P$ Value $=0,001$ kurang dari 0,05

\section{Tabel 2}

Hubungan Riwayat Imunisasi BCG dengan Kejadian TB Paru pada Anak di Poli Anak RS Husada pada Maret 2015 - April tahun $2015(n=41)$

\begin{tabular}{|c|c|c|c|c|c|c|c|}
\hline $\begin{array}{c}\text { Riwa } \\
\text { yat }\end{array}$ & \multicolumn{4}{|c|}{ Kejadian Tb } & \multicolumn{2}{|c|}{$\begin{array}{c}\text { Total ( \% ) } \\
\text { P Value }\end{array}$} & \multirow[t]{2}{*}{$\mathbf{P}$} \\
\hline Imun & \multicolumn{2}{|c|}{$\mathbf{Y a}$} & \multicolumn{2}{|c|}{ Tidak } & & & \\
\hline BCG & $\mathrm{F}$ & $\%$ & $\mathrm{~F}$ & $\%$ & $\mathrm{~F}$ & $\%$ & \\
\hline $\mathrm{Ya}$ & 21 & 51,2 & 8 & 19,5 & 29 & 70,7 & \\
\hline Tidak & 7 & 17,1 & 5 & 12,2 & 12 & 29,3 & $0,3 / 8$ \\
\hline Total & 28 & 68,3 & 13 & 31,7 & 41 & 100 & \\
\hline
\end{tabular}

Dari tabel 2 terlihat bahwa dari 29 anak yang di imunisasi BCG terdapat 21 anak $(51,2 \%)$ menderita TB Paru, dan dari 12 anak yang tidak di imunisasi BCG terdapat $7(17,1 \%)$ menderita TB Paru. Secara statistik dengan melihat derajat signifikasi didapat tidak ada hubungan yang bermakna antara imunisasi BCG dengan kejadian TB Paru pada anak dengan $P$ Value $=0,378$. Karena 0,378 lebih dari 0,05.

\section{PEMBAHASAN}

Kejadian TB Paru pada anak di Poli Anak RS Husada pada bulan Maret 2015 April 2015, berdasarkan hasil analisa univariat kejadian TB Paru pada anak terlihat bahwa dari 41 responden yang berobat ke Poli Anak RS Husada terdapat 28 anak (68,3 \%) yang menderita penyakit tuberkulosis paru dan 13 anak $(31,7 \%)$ tidak menderita TB Paru. Tuberkulosis (TB) adalah penyakit infeksi akibat kuman Mycobacterium Tuberkulosis. Sehingga dapat mengenai semua organ tubuh dimana lokasi terbanyak di paru yang biasanya merupakan lokasi infeksi primer (Mansjoer, 2000). Hal ini sangat disayangkan karena pada usia anak -anak penyakit TB mudah menyebar ke bagian tubuh lain.Mula - mula bersarang di paru - paru melalui aliran darah kuman dapat menyebar ke bagian tubuh lainnya, terutama otak, ginjal, jantung dan tulang. Keterlambatan mendiagnosa dapat menyebabkan komplikasi yang serius seperti meningitis dan pericarditis. 
Sehingga dapat menyebabkan kematian dan jika hidup pun akan menimbulkan kecacatan (Jurnal Respirologi, 2000).

Wahyu (2008) mengungkapkan bahwa faktor yang berhubungan dengan terjadinya TB Paru pada anak antara lain: kontak erat dengan orang dewasa yang menderita TB disekitarnya (orang tua , kerabat dekat, pengasuh), kurangnya kesadaran orang tua untuk segera melakukan vaksinasi BCG pada bayi baru lahir.

Hasil analisa didapatkan temuan tentang satu variabel yang memenuhi hubungan yang signifikan yaitu riwayat kontak dengan penderita TB Paru dewasa terhadap kejadian TB paru pada anak sedangkan variabel satunya tidak memenuhi hubungan yang signifikan sehingga desain penelitian yang tadinya menggunakan analisa bivariate sekarang hanya memakai analisa univariat.

Hasil analisa bivariat antara hubungan riwayat kontak dengan penderita TB Paru dewasa terhadap kejadian TB Paru pada anak dimana didapatkan hasil temuan analisa bahwa terdapat hubungan yang signifikan antara riwayat kontak dengan penderita dewasa terhadap angka kejadian TB Paru pada anak dimana hasil temuan analisanya didapat $P$ Value $=$ 0,001 kurang dari 0,05 .

Hasil ini sesuai dengan penelitian yang dilakukan oleh Azis (2009) dengan judul faktor terjadinya TB paru pada balita di Singigi Provinsi Riau menyatakan balita yang memiliki riwayat kontak dengan penderita BTA positif, resiko terkena TB 2,629 kali lebih besar dibandingkan dengan balita yang tidak ada riwayat kontak dengan penderita BTA positif dan secara statistik bermakna dengan $P$ value $0,01(\mathrm{p}<0,05)$. Sumber penularan adalah penderita TB dengan BTA positif pada waktu bersin atau batuk, penderita menyebarkan kuman ke udara dalam bentuk droplet atau percikan dahak.Daya penularan dari seorang penderira ditentukan oleh banyaknya kuman yang dikeluarkan dari parunya (Depkes, 2002).

Balita yang menderita TB Paru kebanyakan karena penularan dari penderita dewasa. Penularan penyakit tuberkulosis dari udara yang tercemar oleh mycobacterium tuberkulosis yang dikeluarkan oleh penderita saat batuk dalam bentuk droplet (percikan dahak), balita dapat terinfeksi kalau droplet tersebut terhirup kedalam saluran 
pernafasan lalu menyebar dari paru-paru kebagian tubuh vital lainnya (Depkes RI, 2005).

Kuman yang masuk ke dalam tubuh melalui pernafasan dapat menyebar dari paru - paru ke bagian lainnya, melalui system peredaran darah, system saluran limfe, saluran nafas atau penyebaran langsung ke bagian- bagian tubuh lainnya. Kemungkinan seseorang terinfeksi tuberkulosis ditentukan oleh konsentrasi droplet per volume udara dan lamanya mengirup udara tersebut.Kontak yang terus menerus dengan penderita tuberkulosis akan menyebabkan anak terinfeksi kuman mycobacterium tuberculosis, walaupun kuman tersebut bersifat dormant (Fitriatun, 2002).

Penderita tuberkulosis merupakan sumber utama penularan basillus pat disimpulkantuberkel. Orang - orang yang kontak dengan penderita secara mikroskopis sputumnya positif mikobakteri dan 20 - $25 \%$ nya telah terinfeksi. Penyebaran basillus tuberkel dapat dicegah dengan mempertahankan pengendalian udara yang cukup atau penyinaran ultraviolet, atau meminta penderita menutup hidungnya dan mulutnya apabila batuk atau memakai masker sampai pulasan sputumnya dikonversi menjadi negative dengan pengobatan (Shulman dan Firtiatun, 2002).

Berdasarkan hasil analisa bivariat antara riwayat imunisasi BCG terhadap kejadian TB Paru pada anak dimana didapatkan hasil temuan analisa dengan $\alpha=0,05$ dan $p$ value sebesar 0,378 maka dapat disimpulankan bahwa tidak ada hubungan yang signifikan antara riwayat imunisasi BCG terhadap kejadian tuberkulosis paru pada anak.Tidak bermaknanya variabel ini baik anak yang menderita tuberkulosis paru maupun anak yang tidak menderita tuberkulosis paru hampir semuanya telah diimunisasi BCG, karena terjadinya TB paru dapat disebabkan oleh beberapa faktor antara lain: faktor kebiasaan keluarga penderita tidak menutup mulut dengan sapu tangan saat batuk atau bersin,meludah di lantai atau sembarangan tempat, faktor lingkungan dan perumahan terutama sirkulasi udara yang kurang baik sehingga mengakibatkan anak dapat menderita tuberkulosis paru. Peningkatan status gizi berpengaruh terhadap peningkatan daya tahan tubuh dalam menghadapi kuman penyakit, semakin baik status gizi anak semakin baik pertahanan diri dari 
beberapa penyakit infeksi seperti tuberkulosis paru (Depkes RI, 2002).

Hasil penelitian ini menunjukkan bahwa $52,0 \%$ balita yang sudah diimunisasi BCG masih terinfeksi kuman TBC.

Hasil ini sesuai dengan penelitian yang dilakukan oleh Dudeng (2006) dengan judul faktor-faktor yang berhubungan dengan kejadian TB pada anak di Kabupaten Gunung Kidul Provinsi Daerah Istimewa Yogyakarta menyatakan status imunisasi BCG tidak mempunyai hubungan dan bukan merupakan faktor risiko terjadinya TB pada anak dengan nilai OR sebesar 1,66 dengan CI 95\%: $85<\mathrm{OR}<3,24$ dan $P$ Value $=0,18<\alpha=$ 0,05 .

Vaksin BCG dapat mencegah infeksi TB, dan dapat mengurangi risiko $\mathrm{TB}$ berat seperti meningitis TB dan TB millier (Dudeng, 2006). Berkurangnya perlindungan oleh BCG dimungkinkan terjadi karena banyak faktor misalnya prosedur pemberian BCG yang tidak efektif dan efisien. Efektivitas imunisasi BCG sangat tergantung pada berbagai aspek antara lain mutu vaksin, dosis pemberian, waktu dan cara pemberian.

Tidak semua kontak dengan penderita dewasa dan tidak semua imunisasi BCG dapat menimbulkan penyakit tuberkulosis paru anak dari penjelasan diatas terdapat 25 anak $(61 \%)$ kontak dengan penderita dewasa tetapi yang menderita tuberkulosis paru ada $22(53,7 \%)$. Dan pada 29 anak $(70,7 \%)$ yang di imunisasi BCG terdapat 21 anak $(51,2 \%)$ yang menderita TB paru.

Kejadian tuberkulosis paru pada anak di Poli Anak RS Husada dipengaruhi oleh faktor anak tinggal serumah/ kontak dengan penderita tuberkulosis paru, anak yang tidak mendapat imunisasi BCG. Hal ini dapat dilihat dari data yang diperoleh bahwa terdapat anak yang kontak dengan penderita dewasa 25 anak yang mengalami tuberkulosis paru yaitu sebanyak $22(53,7 \%)$. Dan balita yang di imunisasi BCG sebanyak 29 anak yang mengalami tuberkulosis paru sebanyak 21 $(51,2 \%)$.

\section{DAFTAR PUSTAKA}

Alimul Hidayat, Aziz. 2007. Metode Penelitian Keperawatan dan Tehnik Analisis Data. Jakarta: Salemba Medika

Badan Penyelenggara Jaminan Sosial. (2013). Panduan Praktis Pelayanan Imunisasi

Bappenas. (2005). Kebijakan Pemberantasan Wabah Penyakit Menular. Di Akses dari 
http://theindonesiainstitute.com.

Brunner and Suddart. (2002). Keperawatan Medikal Bedah. Edisi 8. Jakarta: EGC.

Crofton,dkk. (2002). Tuberkulosis Klinis. Edisi 2. Jakarta: Widia Medika.

Dahlan, Muhammad Sopiyudin (2008). Statistic untuk Kedokteran dan Kesehatan, Salemba medika, Jakarta.

Depkes, RI . (2002). Pedoman Nasional Penanggulangan Tuberkulosis. Jakarta.

Dudeng, Donatus, dkk. (2006). Faktorfaktor yang Berhubungan dengan Kejadian Tuberkulosis pada Anak di Kabupaten Gunung Kidul,Provinsi Daerah Istimewa Yogyakarta. Berita Kedokteran Masyarakat Vol.22 ,No.2 ,Juni 2006. Hal ; 48-54

Fitriatun, (2002). Kondisi Rumah Sebagai Faktor Risiko Tuberkulosis Paru pada Balita yang Berkunjung di BP4 Semarang Tahun 2002. Program Pasca Sarjana Universitas Diponegoro Semarang.

Hidayat, A. Aziz Alimul. (2007). Riset Keperawatan dan Teknik Penulisan Ilmiah edisi kedua. Jakarta: Salemba Medika.

IDAI, (2009). Diagnosis dan Tatalaksana TB Anak. Depkes RI. Jakarta.

Islamiati, dkk. (2009). Faktor-faktor yang Mempengaruhi Kejadian Tuberkulosis Paru Pada Balita di Poliklinik Anak RSU A. Yani Metro, Jurnal Kesehatan " Metro Sai
Wawai " Volume II no.2 Edisi Des 2009,19779-469X. Hal ; 63 - 70.

Kemenkes, RI. (2013). Pedoman Nasional Pelayanan Kedokteran Tatalaksana TB.

Volume 13. Jakarta: Sari Pediatri.

Masjoer, Supriatia, Wahyu Ika Wardani, Wiwik Seto Wulan. (2000). Kapita Selekta Kedokteran. Jakarta: EGC.

Manurung, (2009). Penyakit Infeksi Saluran Pernafasan. Jakarta: EGC/

Natalia P, Ali. (2013). Keterampilan Imunisasi. Surakarta: FK UNS

Ngastiyah. (2009). Perawatan Anak Sakit. Jakarta: EGC.

Nurhidayah, Ikeu, dkk. (2007). Hubungan Antara Karakteristik Lingkungan Rumah Dengan Kejadian Tuberkulosis (TB) Pada Anak di kecamatan Paseh Kabupaten Sumedang. Bandung: Universitas Padjajaran Fakultas Ilmu Keperawatan.

Nursalam. (2009). Konsep dan Penerapan Metodologi Penelitian Ilmu Keperawatan. Pedoman Skripsi, Tesis dan Instrumen Penelitian Keperawatan. Jakarta: Salemba Medika.

Perhimpunan Dokter Paru Indonesia. (2000). Jurnal Respirologi Indonesia Vol. 20. Jakarta: FKUI.

Setiadi, (2013). Konsep Penulisan Riset Keperawatan. Edisi 2. Jakarta

Sudoyo, Aru W. (2006). Buku Ajar Ilmu Penyakit Dalam. Jakarta: 
Departemen Ilmu Penyakit Dalam FKUI.

Suriadi, Rita Yuliani. (2006). Asuhan Keperawatan Pada Anak. Jakarta: Sagung Seto.

Wahyu, GG. (2008). Panduan Praktis Mencegah dan Mengobati TBC pada Anak. Jakarta: Dian Rakyat.
Stanhope, M., \& Lancaster, J. (2014). Fondations of nursing in the community: comunity-oriented Practice. Fourth edition, Mosby :St Louis Missouri.

United Nations. (2002). World Population Ageing 1950-2050. Population Division. DESA, United Nations.

Wolfe,C.D.(2000). The impact of stroke . British Medical Bulletin 2000, 56 (No 2) 275-286 